\title{
Transformation of the Urban Pattern in Istanbul: From Multi-Storey Dwellings to Gated Communities
}

\author{
Istanbul'da Kentsel Dokunun Dönüşümü: Çok Katlı Konutlardan Kapalı Sitelere
}

\author{
Tuğçe EREN, Neslihan DOSTOĞLU
}

ABSTRACT

The rapid and unrestrained transformation of traditional housing patterns, generally based on the experience and cultural background of the inhabitants, as a result of different requirements and new building techniques, has caused various urban problems all over the world. Turkey has also encountered these problems during the development process of multi-storey dwellings that have ignored the existing urban pattern starting from late $19^{\text {th }}$ century. This study deals with the transformation engendered by implementing blocks of multi-storey apartments in İstanbul, starting from the $19^{\text {th }}$ century, and its effects on the social and physical environments. In fact, the new dwellings have influenced not only the urban pattern, but also social life. In this context, the influence of new building types on the urban pattern transformation and their effects on urban memory are evaluated. Various researchers have expressed their concern for considering dwellings separately from their environmental contexts. Unfortunately, environments integrating dwellings and their surroundings have become difficult to find in Turkey. Within the mass production mentality, new dwelling forms proliferating rapidly with various requirements and interests have invaded cities in the form of concrete blocks and have become estranged from the existing environment. Istanbul was selected in this study because it has been largely influenced by the modernization process and incorporates different building techniques and forms more than other Turkish metropolitan cities. This study aims to evaluate how the rise of multistoried dwellings in the $19^{\text {th }}$ century, a historical districts in Istanbul, affected social life and how continuing this architectural approach has transformed the existing urban environment.

Keywords: Historic environment; multi-storey buildings; development of dwellings.

Pek çok ülkede tarihi ve doğal çevreler zaman içerisinde sosyo-kültürel, ekonomik, politik etkenler doğrultusunda dönüşüme maruz bırakılmıştır. Mevcut kent dokusu içinde insanların uzun yıllar boyunca deneyimleyerek oluşturdukları ve kültürel yapılarının bir yansıması olan geleneksel konut dokularının, çeşitli dönemlerde ortaya çıkan farklı gereksinimler doğrultusunda ve yeni yapım tekniklerinin kullanımıyla hızla ve kontrolsüz bir biçimde dönüşmesi, kentsel sorunlara sebep olmuştur. Türkiye'de de bozulma sürecini tetikleyen en önemli unsur çok katlı konut yapılarının kentin mevcut dokusunu göz ardı ederek çoğalması olmuştur. Bu makalede çalışma alanı olarak seçilen İstanbul'da, 19. yüzyıldan itibaren inşa edilen çok katı konutların yarattığı değişim analiz edilmekte, sosyal ve fiziksel çevre üzerindeki etkileri sorgulanmaktadır. Makalede yeni mimari anlayışın insan ve kent yaşamını dönüş̧ürmesindeki hızı irdelenmekte ve günümüzde tüm kenti etkisi altına alan bu yapılaşmanın kent belleğine olan etkileri değerlendirlmektedir. Çağdaşığın biçimsel bir ifadesi olduğu düşünülen çok katlı konutlar, yalnızca kent dokusunu değiştirmekle kalmamış, kullanıcıların yaşamlarını da derinden etkilemiştir. Çeşitli araştırmacılar, konutun bulunduğu yerden ayrı düşünülemeyeceğini, çevresiyle bir bütün olduğunu ifade etmektedir, ancak Türkiye'de konut ve çevre bütünlüğünün bulunduğu yaşam çevrelerine rastlamak giderek güçleşmektedir. Kitlesel üretim mantığında, ihtiyaç ve çıkarlar doğrultusunda hızla çoğalan ve kolektif yaşam biçimini barındıran yeni konut formları, değinilen sebeplerle günden güne bulunduğu çevreye yabancılaşmakta ve beton yığınları biçiminde kenti istila etmektedir. Modernleşme sürecinden en çok etkilenen bölgelerden olması ve diğer metropollere oranla farklı yapı tekniği ve formlarını bünyesinde barındırması dolayısıyla Istanbul bu çalışma için örnek olarak seçilmiştir. Bu makalede yeni mimari arayışların etkisiyle İstanbul'da 19. yüzyıldan itibaren giderek yükselen çok katlı konut formlarının insan yaşamını nasıl etkilediği, süregelen bu modern mimari anlayışın kentin mevcut dokusunu nasıl değiştirdiği ve günümüz kentindeki durum incelenmektedir.

Anahtar sözcükler: Tarihi çevre; çok katı konut yapıları; konutun gelişimi.

Department of Architecture, İstanbul Kültür Universty Faculty of Architecture, İstanbul, Turkey.

Article arrival date: October 09, 2015 - Accepted for publication: April 25, 2017

Correspondence: Tuğçe EREN. e-mail: tgc.eren@gmail.com

๑ 2017 Yıldız Teknik Üniversitesi Mimarlık Fakültesi - ๑ 2017 Yıldız Technical University, Faculty of Architecture 


\section{Introduction}

Traditional dwellings interrelate with the social and cultural values of the society as well as the physical environment in which they are built. In this context, the transformation of traditional housing areas throughout history cannot be evaluated through the limited scale of buildings, but through a wider scale including the social and physical environment. Hasol (1967) mentions that there are two major transformation periods that have changed the understanding of a shelter. The first one is the shift from nomadism to civilization, and the other one is the transition from agriculture to industrial period. While the first transition has occurred gradually with the transformation of the regional structure in a long period, the second transformation has occurred so fast that many buildings constructed in the industrial period have not been able to establish a lasting relationship with their environment. ${ }^{1}$ In fact, after the Industrial Revolution, starting in England during the second half of $18^{\text {th }}$ century, the construction sector experienced a series of important changes as a result of the application of mass production processes. Simultaneously, together with industrialization, resulting in uncontrolled migration to urban centers, significant transformations were seen in the urban pattern. Various types of new residential areas were constructed in an uncontrolled way, leading into unplanned urban development.

As the influences of industrialization became widespread in the world with time, traditional houses continued to be replaced by new housing types, ranging from apartment blocks to detached houses and gated communities for various income groups in urban areas in many countries, including Turkey. However, as Rapoport (1969) ${ }^{2}$ has indicated, the transformations implemented in a short period of time with the decisions taken from above have brought about negative results, since changes in the physical environment were usually not consistent with the social and cultural structure. Unfortunately, the natural environment has also suffered during this process. In many countries in the world, a large percent of green and public areas have been privatized, agricultural areas have been destroyed, forests have been burnt down, historical buildings have been neglected, and urban memory has been mostly erased during this process.

This paper aims to investigate and discuss the transformation of housing areas in Istanbul as a case during the industrialization process starting in late Ottoman era and continuing into the Republican era; more precisely the way that multi-storey dwellings developed in Istanbul and their reasons in general, and how the life of inhabitants were influenced in this process. In short, the way that the pres-

\footnotetext{
1 Hasol, 1967.22 Rapoport, 1969.
}

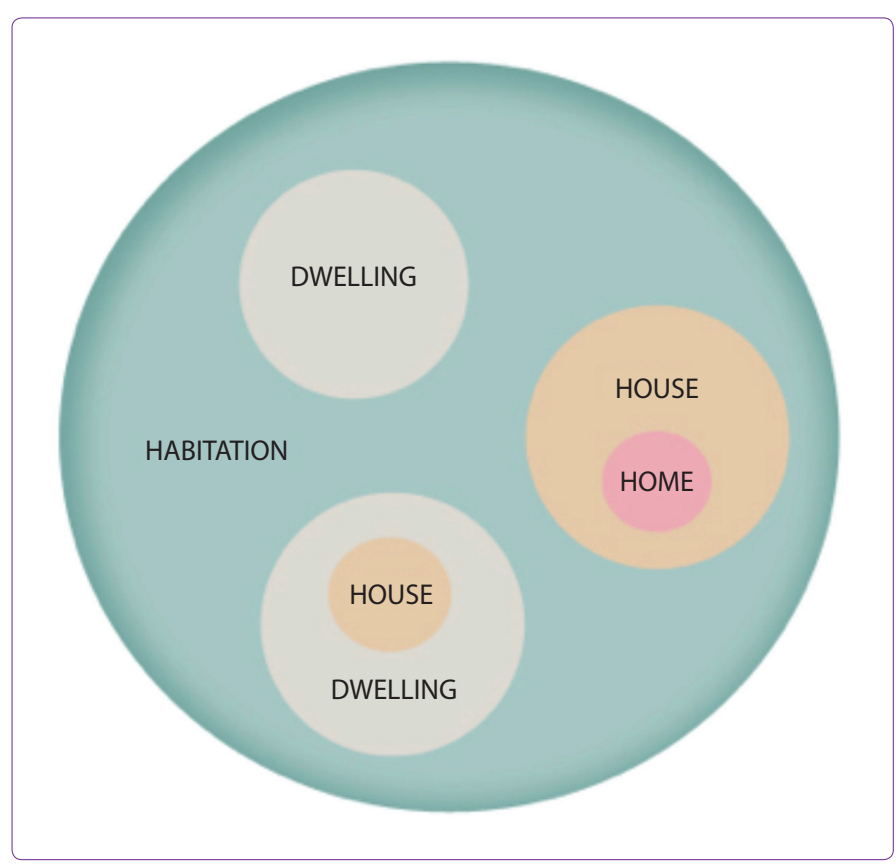

Figure 1. Schematic representation of the definitions.

ent density of high rise dwellings in Istanbul, which first appeared in Galata during the $19^{\text {th }}$ century and expanded rapidly, leading the city to become a concrete heap vertically and horizontally, and affecting the physical and social environment, is evaluated in this paper.

\section{Conceptual Framework of the Transformation in the Physical and Social Environment}

Frequently used concepts such as 'habitation', 'dwelling', 'house' and 'home' differentiate in their meanings, according to the ways that they are described or perceived. The concept of 'habitation ' does not portray an area which is for long-term and compulsory living, as the concept of 'dwelling' depicts. Furthermore, shelters, tents, caves etc., where people used to live in order to be protected from environmental conditions during prehistoric period, were not 'houses'. 'House' and 'home' mean much more than a space to sleep and eat, differing from the concept of dwelling. A 'house' gains the qualification of a 'home', when it becomes a life space where happiness and sadness, joy and social values are expressed. Thus, it can be stated that each house is a dwelling, but each dwelling is not a house or home (Figure 1). As Cooper-Marcus (1995) has stated, a home is an "identity symbol". ${ }^{3}$ In this study, the word 'dwelling' has been used in general, unless the emphasis is on 'house' and 'home' in specific evaluations.

One of the main factors affecting the lives of people and causing major changes in dwelling forms is Industrial Revolution and its related attributes, such as mass production,

3 Cooper-Marcus, 1995. 
mechanization, population growth, transportation and infrastructure improvement, and rapid urbanization. In addition, the opportunities provided by the constantly evolving technology in relation to materials and construction techniques, the development of the communication sector, political decisions, such as zoning regulations, have also been important factors affecting dwelling form. Mass production, which is the main attribute of the Industrial Revolution, has enabled the acquisition of a large number of products with less labor in a short time. Thus, in the process of designing objects in pieces and producing each piece in a series to be combined in an assembly line, hundreds of products have been obtained. Through this system that ensures the standardization of objects, practical solutions on furniture, building materials and construction techniques were provided. In the third quarter of $18^{\text {th }}$ century, the rapid developments in transportation and communication technologies the breakage of closed economy and local accumulation possibilities have accelerated construction activities.

\section{A New Dwelling Type: Its Effects on the Physical and Social Environment in İstanbul During the $19^{\text {th }}$ Century}

When the effects of the Industrial Revolution spread from England in the $18^{\text {th }}$ century to other countries in the world, including the Ottoman Empire, new developments took place in the Empire during the $19^{\text {th }}$ century. In fact, Ottoman cities experienced social, economic and physical transformation processes not due to internal dynamics, but rather due to external influences during the 19th century which can be generally defined as a period during which the Ottomans followed Western organizational practices.

In this study, Istanbul was chosen as one of the most affected regions from the modernization process of the Ottoman Empire during the $19^{\text {th }}$ century. Changes in dwelling types were seen during the last quarter of the $19^{\text {th }}$ century in Istanbul, which became a commercial center in the context of rapid changes taking place during this period. Wooden houses, which were widely constructed until that period, experienced damages due to fires. As a solution to the fire problem, multi-storey masonry dwelling forms, which were widespread in Europe, were implemented first by non-Muslims in Galata-Pera district. This approach caused Galata region to develop in a different way from many other regions in Istanbul. This difference was enhanced even more when the existing housing stock became insufficient because of the rapidly growing population in the region, as Galata District became a busy commercial center in time. The utilization of the ground floors of dwellings as shops restricted the areas allocated for housing even more, and led to vertical solutions together with the rise in land prices. In addition, implementation of

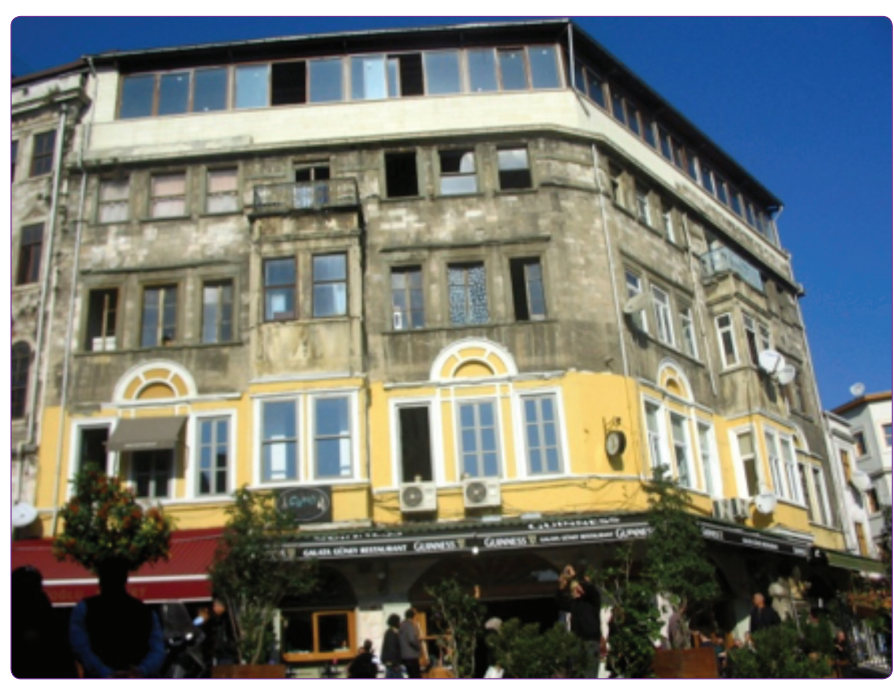

Figure 2. Cuppa apartment (1858-1874) in Galata/Istanbul (Eren, 2014).

urban plans was an important factor increasing the speed of multi-storey dwelling construction. These changes taking place at the end of the $19^{\text {th }}$ century constituted the beginning of apartments that can be described as multifamily dwellings. The rise of multi-storey dwellings under the leadership of Levantine families in Galata-Pera region, influenced the region, and the city in general in a short period of time. ${ }^{4}$

However, the tendency to increase in height parallel to the reduction in the size of inner city parcels led to some problems. Population density brought about solutions for relating housing units not only horizontally, but also vertically, and the resulting blocks were generally so identical that they multiplied independently from place (environment) and subject (identity). In this context, these dwellings, which resembled not only the height characteristics, but also facade forms and plan orders in Europe would have the same influence if they were relocated in another place, because they were not integrated sufficiently with the environment (Figure 2).

Since the $19^{\text {th }}$ century, the urban pattern of İstanbul has continued to change radically due to economic and political factors. While living in detached dwellings was considered as a privilege for families, and dense areas where many families lived together were perceived as low-income previously, a cultural turning point occurred together with upper-income groups preferring to live in multi-storey housing blocks, which offered a new spatial order. Thus, there was an increasing demand for new multi-storey dwelling blocks for upper-income groups in istanbul during the $19^{\text {th }}$ century. In contrast to their mental image, multi-storey dwellings initially built for the lower income group of

\footnotetext{
${ }^{4}$ Öncel, 2010.
} 


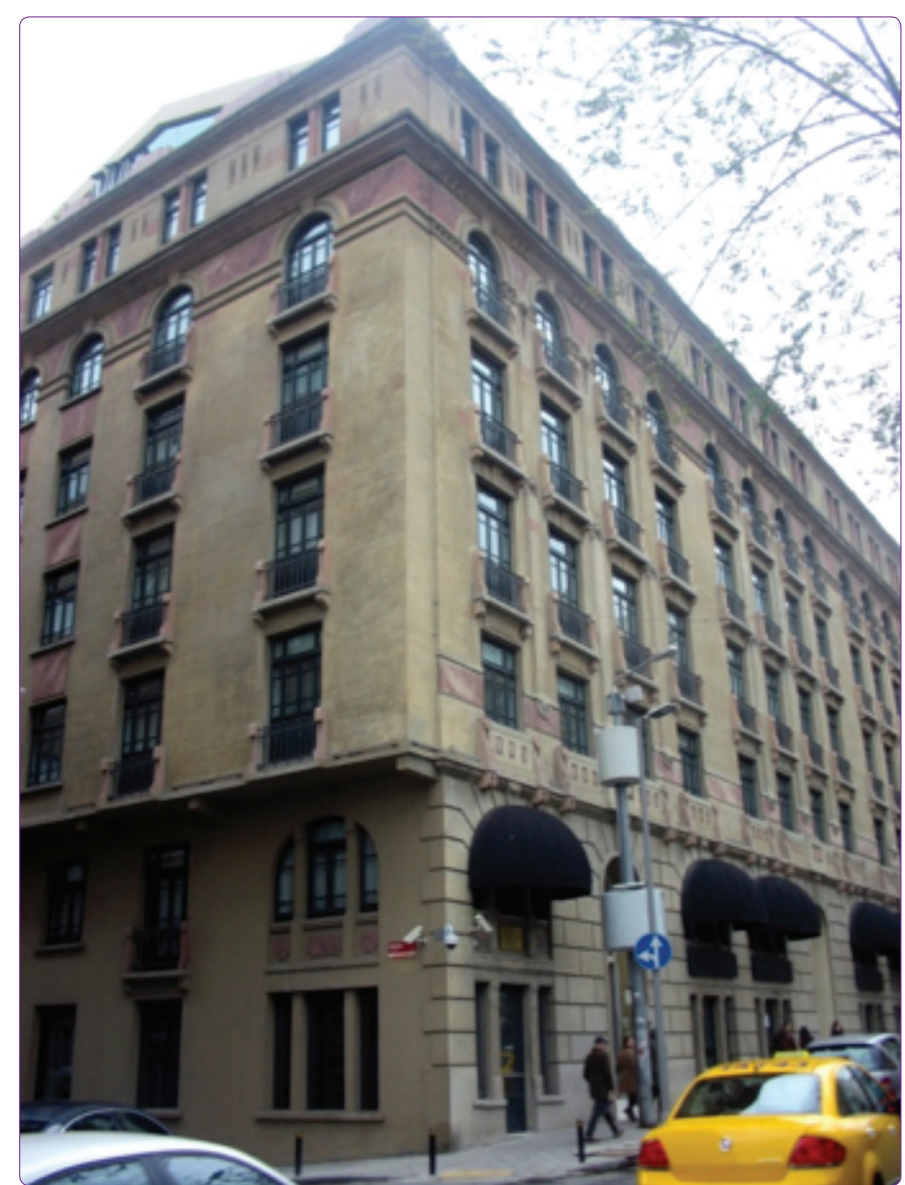

Figure 3. Maçka Palas (1922) in Şişli/lstanbul (Eren, 2014).

workers in Europe, were addressed largely to middle class and upper income groups in Turkey due to their capacity in raising life standards, such as providing ventilation, solving heating problems, and being comfortable (Figure 3). In fact, factors such as the provision of services, creation of alternatives in interior space organization and in the physical environment of the dwellings, have been important for changing the taboos in the minds of users. Thus, 2 or 3 storey houses for extended families were transformed into apartment blocks where nuclear families started to live. ${ }^{5}$ Finally, the Flat Ownership Law (1965) made individual property ownership of independent units such as flats, shops, storages possible. Consequently, the understanding of rental housing was replaced by family houses for sale. ${ }^{6}$

\section{Transformation in the Housing Pattern of Istanbul During the $20^{\text {th }}$ Century}

With increasing technological support in rural areas, and developing industry in cities in Turkey after the 1950s, job opportunities for people living on agriculture and animal husbandry decreased. Massive migration from rural areas to the cities, which had more working opportunities,

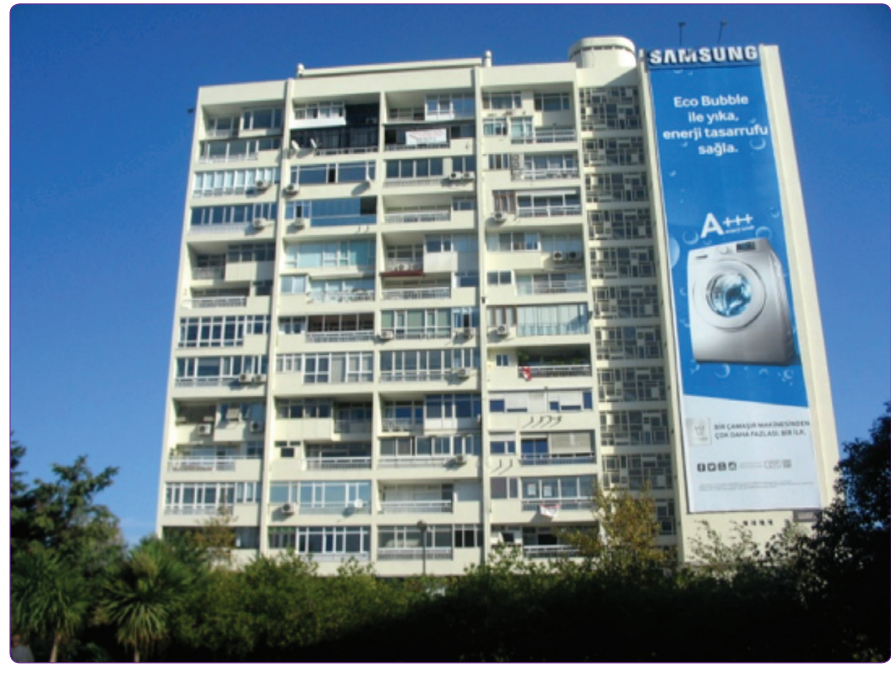

Figure 4. Hukukçular Sitesi (1958-1967) in Şişli/Istanbul (Eren, 2014).

caused rapid urbanization. The need for housing rose drastically due to population growth, which increased more than the existing housing stock, and this situation brought about unplanned urban development. Squatter housing areas were developed, as a new type of housing, by lowincome groups who migrated from villages and could not adapt to city life in the 1950s. As an alternative to squatter housing, Emlak Konut (Real Estate Dwelling) Bank began to give loans as an incentive to lower and middle-income groups, and mass housing and housing cooperatives were established in this process (Figure 4). These changes have led into apartment buildings being constructed in almost all of the parcels open for development in urban areas. ${ }^{7}$ After all these efforts paving the way for private enterprise in the 1950s, and the establishment of the State Planning Organization in 1960, the housing market developed. Thus, the tendency to rise, that began to be perceived as an indication of development, which caused an increase in the number of floors in different regions of Istanbul, also started to control the life style of people.

In short, due to the desire to increase profit, dwellings have become commodities on the market and have entered a rapid process of transformation in the $20^{\text {th }}$ century. This rapid transformation in İstanbul has caused an increase in the number of buildings that have no relation with their physical environment, and which are usually far from meeting the values of the users (Figure 5). Thus, the memory of neighborhood culture, which is so deeply rooted in various regions of Turkey, has almost disappeared, being gradually replaced by introverted gated communities.

In short, advances in technology have affected the housing market both physically and socially. Technological im- 


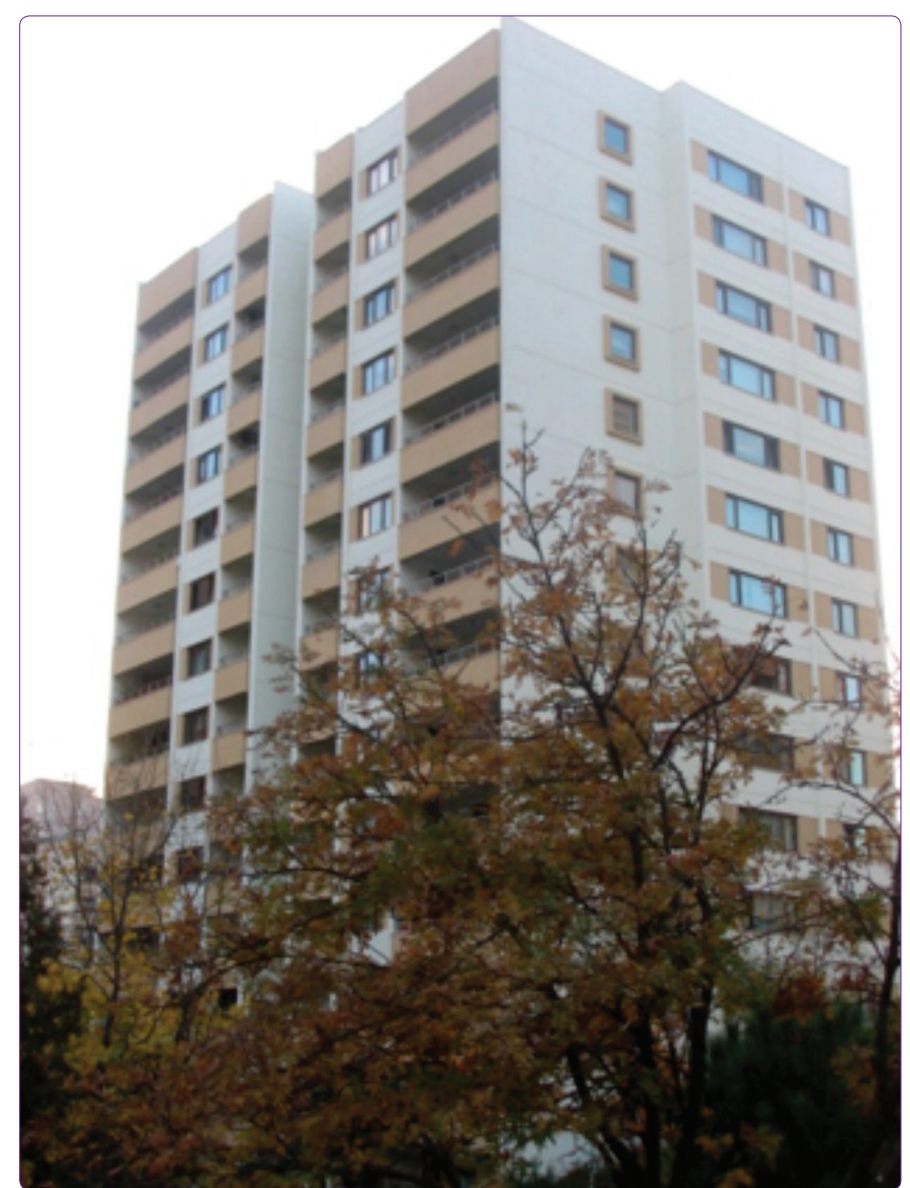

Figure 5. Feneryolu Apartment (1958-1967) in Kadıköy/Istanbul (Eren, 2014).

provements have allowed user needs to be met in a short period of time and in desired numbers. While individually tailored goods were produced as a result of human labor continuing sometimes for months in the past, hundreds of single products have been available on shelves after industrialization. These processes were also influential in dwelling types and flats, which all started to be identical with each other. In short, housing units, which were planned according to the needs of users and which embodied the cultural values of people, were exposed to changes due to political, commercial, physical and social reasons. These changes not only influenced the social environment, but also caused permanent damages in the urban pattern.

Shopping, entertainment and sports centers started to be included among multi-storey dwelling blocks in the dense urban fabric. With this setup, multi-storey dwelling types, which comprised mixed usage, started to reflect the concept of "closedness". In this context, the effects of a new culture in harmony with the period were seen in the development of gated communities and the inclusion of commercial activities within these communities, where different types of individuals came together.
In today's metropolis, individuals from various different backgrounds tend to work. The former family concept, which was based on the idea that women stay at home, and men bring money, has disappeared. Since children go to school, and men and women go to work during the day, home has become a place where family members go at night, prepare dinner or eat outside, and sleep thereafter. However, even though the time spent in the house has decreased, commitment to the house and family keeps its structural characteristics.

Especially when high rise buildings in gated communities involving mixed usage, which are designed for upper income groups, are analyzed, it is seen that people who go to work during the day and come back in the evening, are re-directed to enclosed spaces, such as shopping malls, sports centers, entertainment and food courts, which are built close to their houses. As a result of this system, which cuts off people from city, the usage of open spaces in the city has decreased, and these open spaces have been replaced by building blocks that are expected to bring profit. Although some problems have been resolved with the development of technology, this tendency has put a distance between people and the city, has exposed them to spatial boundaries, and has caused the emergence of an architectural understanding which falls short of answering cultural values, and is unable to reflect the spirit of the place or period.

\section{Changing Space Usage in New Dwellings}

The construction of multiple apartments with similar sizes and spatial relations under the same roof have caused individuals who have different lifestyles and preferences, to desire change and difference from the others. In this context, flexible spaces, which could respond to the constantly changing demands of the $20^{\text {th }}$ century, have begun to be derived. This has allowed users to create their own interior designs so as to suit their life preferences. It can be seen that transformation in the scale of a building not only affects the environment, but also causes an alteration in the lives of inhabitants.

Basically, arrangements that people have made for their necessary requirements have not occurred randomly, but have been planned to ensure a user-friendly life. It is clear that buildings and spatial organizations are mutually complementary parts, forming the whole. When the transformation process of dwellings is evaluated, it can be observed that change is not only related with form, but also with many other factors such as volume, utilization pattern, spatial diversity, comfort, height, technology, culture and privacy. In this context, not only has the relationship among spaces changed continuously in order to keep pace with the modern identity of the period, but also the 
proportions of spaces in the apartments have also been transformed.

The reason for main spaces like "room", "living area" and "kitchen" not being attributed with an identity until the first quarter of the 20th century was due to the lack of specialization of rooms. The reflection of traditional Turkish family structure, which can be described as extended, has brought the need for a single space to be used for multiple functions. One reason for this is that, contrary to the easily-changing dwelling forms parallel to physical and social factors, the family structure does not evolve quickly. In this context, the relationship and proportion of rooms in the apartments of the first multi-storey housing blocks that were built before the Republican Period in Turkey basically reflect the characteristics of traditional Turkish houses. Thus, the provision of functions were optional for users by means of establishing relations among equal sized rooms, taking into consideration the living conditions of the users, which did not change easily.

Constantly changing forms in the capitalist system have transformed horizontal patterns to vertical ones, thus making shopping malls, passages and bazaars parts of multi-storey housing. Commercial spaces were not limited to ground floors, as there were examples of rooftops providing commercial functions between the years 1950 and 1980. The interesting point is that people had to pass from a public space to reach their own private space, which reflected their inner self. In fact, the transition from a space which is used by various individuals at certain intervals in daily life to a space which embodies individual lives, is experienced in these dwelling types. In this scheme, commercial units cause people to comply, by making them dependent, while reducing the boundaries of their private space without notice. This order (lessness) which is an impact of modernism, is reflected clearly in Le Corbusier's Unite d'Habitation designed in 1952, where commercial facilities are spread on different storeys.

Multi-storey residential buildings in Istanbul, which started to be built in Galata-Pera region in the $19^{\text {th }}$ century, were planned and implemented independently from the cultural values of users, and housing selection criteria were directed to different dimensions. As expectations from a dwelling and its environment changed, users began to be interested in the opportunities provided by the environment before checking floor plans, which basically were similar. Especially at the end of the $20^{\text {th }}$ century, a group of professionals who became rich as a result of global economy in Istanbul, a metropolitan city by then, became dependent on a number of consumption habits and began to demand dwellings with different standards. The requested houses were introverted, vertical duplex, semi duplex, garden apartments, having facilities like pools and tennis-

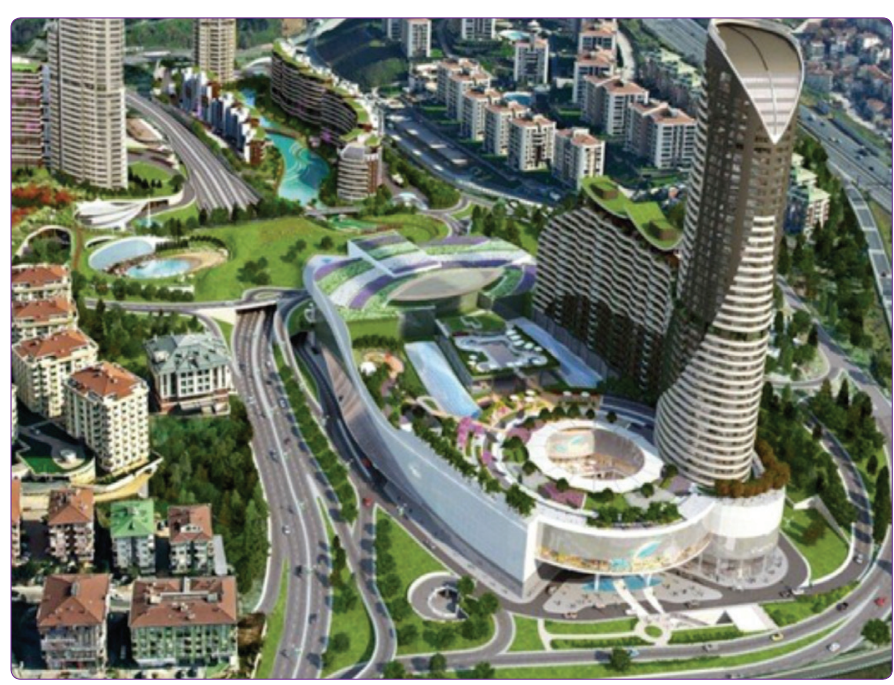

Figure 6. Akasya Acıbadem (2007-2013) in Acıbadem/Istanbul (Eren, 2014).

basketball courts. In this context, a high-rise dwelling form comprising the latest technological improvements was developed, and this form began to be marketed as the answer to contemporary life style. ${ }^{8}$ As the culmination of all these developments in the housing sector, multi-storey residential groups, in which residences and towers are included, have become widespread at present (Figure 6).

Upper income groups preferring these dwellings, which provide all kinds of comfort with intelligent building systems, have almost forgotten how it was like to wash their own clothes and clean their houses. The gated communities have increased the separation between social groups as they reflect explicitly the difference between the residents and the low income groups who work for security, commercial premises or cleaning in these communities. Nowadays, in the process of selling the apartments, the size of the main spaces and the location the apartment building have a major role in setting the price. An analysis of the apartments' general characteristics demonstrates the dominance of straight and smooth square/rectangle shapes in the interior.

Simple and featureless spaces and the presentation of identical units for everyone has become the norm because of the impossibility of providing specific units for the users who have different backgrounds. Thus, "monotype" apartments are offered to each user. In the absence of separators, the spaces do not allow different designs according to the will of the users. In this planned scenario, the quality of spaces and their relationship with each other do not have importance or priority. In this context, most of the time the level of satisfaction differs for users, even though they live in the same type of apartment. A family who has the same apartment plan as another, might be happy ac-

\footnotetext{
8 Edgü, 2003
} 
cording to their life style, while another could be totally unsatisfied.

Proliferation of individualism together with changes in life style has led apartments to be reduced to $1+1$ and $1+0$ sizes. One important point in the formation of this apartment type is the kitchen area, which has contributed to the further reduction of dwelling units. This form has been preferred especially after 1950s, under the influence of minimalized American kitchens and so-called open kitchens. The most important reason in the choice of such small apartments has been the changing demographic structure. The transformation of large families to nuclear families has also decreased the need for large spaces. Constantly changing demands, reduction in sharing, lack of time spent at home, have affected the memory of dwelling and deprived it from the concept of 'home'.

\section{Evaluation}

The effects of multi-storey dwellings in Istanbul, which have first developed according to the requirements in the historic Galata Region under the influence from the West, in transforming the urban pattern did not proceed in a planned way as expected. Emphasizing the necessity for each dwelling form to be developed in relation to its region and close environment and to be a product of a specific place and society, it can be stated that the spread of culturally incompatible housing forms in urban areas as a result of imposed decisions, have not been able to provide a comfortable life-style as imagined. In particular, when the power of private sector in housing market increased, the number of dwellings that are profit-oriented and without aesthetical concern have increased as well. The buildings for low-income groups, such as mass housing and cooperatives, have changed people's living conditions and expectations due to their general appearance without identity and their copied floor plans. When different multi-storey dwelling groups began to appear for different income groups, the urban area was divided into specific regions separated according to income levels, and 'otherization ' has become a social problem in this process. The background discourse of this problem is that if the income is good enough, the right to choose also increases, and in case the contrary is valid, the right to choose disappears. While various types of apartments, such as vertical duplex, semi duplex, have been designed in multi-storey dwellings for upper-income groups, fewer plan types have been proposed for low income groups, based just on family sizes, such as $1+1,2+1$, and $3+1$ types.

In the $19^{\text {th }}$ century, the first multi-storey dwellings in Galata Region were able to keep alive the neighborhood concept because they were integrated well with the traditional urban pattern. Although housing blocks in the area ascended vertically, because of the interaction among them, social relations in the neighborhood persisted. However, when multi-storey dwellings began to spread in various regions of the city, they either existed as singular blocks or as introverted group of blocks. In either case, a large number of undefined multi-storey dwelling blocks, unable to be integrated with the city, began to rise everyday, impairing the silhouette of Istanbul.

Another social factor affecting dwelling forms has been the increase in people's working hours. Fathers used to be the only ones working in families in the past, however both parents go to work at present. As children are at school and parents are at work during the day, the names of the spaces in the house have also been transformed because of changed requirements. The reduction of time spent at home has brought about an increase in the consumption of ready made foods, and thus a decrease in the requirement for kitchen space or large living areas due to the difficulties in hosting guests. With the changes in the social habits of individuals, most children have started to spend their time in their bedrooms with their computers. The rise of individualism and the decrease in sharing has resulted in the reduction of the establishment of families. In this context, as the quantity and quality of spaces required in dwellings have changed, $1+1$ and $1+0$ type apartments have increased. Consequently, it can be stated that factors affecting life conditions of individuals have brought about changes in dwelling forms and the concept of 'home' has begun to lose its meaning. The most important reason for this is the reduction of time spent at home and in communication. Besides encouraging individual life-style, apartments such as 1+0 type has become a triggering factor for the minimal and multi-functional furniture sector. In addition, this plan type which is usually seen in intelligent buildings has carried hotel room experience into dwellings, by offering some building services such as cleaning and laundry. The important point is that a hotel room does not have memory and is unable to provide the concept of 'home'. Another expectation of users from advanced building systems is to maintain a spacious balcony or terrace. This expectation is a result of the need to own green spaces at least vertically, as a result of the disappearance of natural green areas in the city.

Dwellings have become fashion and trend objects along with the fact of individuality persisting as a result of the effects of globalization and modernity. As a result, cultural tastes have been left behind, and consumption has been emphasized, exposing housing to 'cultural abstraction'. In short, different spatial orders and tendency to rise are constantly being transformed into new forms by means of changing technology, tastes, preferences, shares, laws, supplies and lives. On the other hand, cultural values have 
lost their influence in time, being substituted by other parameters, such as unlimited requests, instant satisfaction and individualism.

\section{References}

Bilgin, i. (1996) “Anadolu'da Modernleşme Sürecinde Konut ve Yerleşme", Sey, Y. (editor), Tarihten Günümüze Anadolu'da Konut ve Yerleşme, İstanbul, Tarih Vakfi Yayınları, 472-490.

Cooper-Marcus, C. (1995) House as a Mirror of Self: Exploring the Deeper Meaning of Home, Berkeley CA, Conari Press.

Edgü, E. (2003) Konut Tercihlerinin Mekansal Dizin ve Mekansal Davranış Parametreleri ile iliş̧kisi, Doktora Tezi, İstanbul, ìstanbul Teknik Üniversitesi.

Eren, T. (2014) İstanbul'daki Çok Katlı Konut Yapılarında Mekansal Değişim Sürecinin Analizi, Yüksek Lisans Tezi, İstanbul, ìstanbul Kültür Üniversitesi.

Gür, Ş. Ö. (1989) "80li Yıllarda Apartman Örnekleri", Mimarlık, Sayı 233, 62-65.

Hasol, D. (1967) "Yapının Endüstrileşmesi", Mimarlık, Sayı: 40, 9-14.

Keleş, R. (1983) 100 Soruda Türkiye'de Kentleşme, Konut ve Gecekondu, İstanbul, Gerçek Yayınevi.

Keleş, R. (1984) Kentleşme Politikası, Ankara, İmge Kitapevi.

Kıray, M. B. (1979) "Modern Şehirlerin Gelişmesi ve Türkiye’ye Has Bazı Eğilimler", Kentleşme Yazıları, İstanbul, Bağlam Yayınları, 138-141.

Mutdoğan, S. (2014) "Türkiye'de Çok Katlı Konutun Oluşum Sürecinin İstanbul Örneği Üzerinden İncelenmesi", Ankara, Hacattepe Üniversitesi Sosyolojik Araştrrmalar E-Dergisi, 1-27.

Öncel, A. D. (2010) Apartman: Galata'da Yeni Bir Konut Tipi, ìstanbul, Kitap Yayınevi.

Örer, G. (2002) Konut - Kimlik - Ev Modeli ve Modelin Bir Örnek Olarak İstanbul Kentinde Uygulanması, Doktora Tezi, İstanbul, İstanbul Teknik Üniversitesi.

Özakbaş, D. (2007) Cumhuriyet Dönemi (1923-1940) İstanbul Ko- nut Mimarisi, Yüksek Lisans Tezi, İstanbul, Mimar Sinan Güzel Sanatlar Üniversitesi.

Rapoport, A. (1969) House Form and Culture, USA, Prentice Hall.

Rapoport, A. (2004) Kültür Mimarlık Tasarım, çev. Batur, S., İstanbul, Yapı Yayın.

Sey, Y. (1998) "Cumhuriyet Döneminde Konut", Sey, Y. (editor), 75 Yılda Değişen Kent ve Mimarlık, İstanbul, Türkiye Ekonomik ve Toplumsal Tarih Vakf Yayınları, 285-300.

Şener, S. (2000) 1944 Yılı Sonrası Toplu Konut Uygulamalarında Apartman Plan Tipolojileri Gelişimi, Yüksek Lisans Tezi, İstanbul , İstanbul Teknik Üniversitesi.

Şenyapılı, T. (1996) "Yeni Sorunlar Eski Çözümler: Kentsel Mekanda Bir Gecekondu Yolculuğu", Sey, Y. (editor), Tarihten Günümüze Anadolu'da Konut ve Yerleşme, İstanbul, Tarih Vakfi Yayınları, 345-354.

Talu, N. (2012) “Bir Arzu Nesnesi Olarak Ev", E-Dergi Sanat Tarihi, Sayı 2, 1-19.

Tanyeli, U. (2010) "Apartmanlar", İstanbul Ansiklopedisi, İstanbul, NTV Yayınevi, 134-137.

Tekeli, i. (2010) Konut Sorununu Konut Biçimleriyle Düşünmek, İstanbul, Tarih Vakfi Yurt Yayınları.

Türker, E., G. (2010) 21. Yüzyıl İstanbul Büyük Kent Modelinde Bir Yatırım Aracı Olarak Konut Olgusu ve Piyasa Baskısının Mekan Organizasyonları Üzerindeki Belirleyici Etkilerinin Analizi, Yüksek Lisans Tezi, İstanbul, Yıldız Teknik Üniversitesi.

Türkkan, S. (2007) Yoğunlaşan Kent ve Yaşamında Kapasite Arayışları ve İstanbul'a Bakış, Yüksek Lisans Tezi, İstanbul, İstanbul Teknik Üniversitesi.

Uzunarslan, Ş. (2010) “Cumhuriyet'in IIlk Yirmi Yilında Mimarlık Alanındaki Gelişmelerin Mekan ve Mobilyaya Yansıması", Ergut, E. A. ve İmamoğlu, B. (editör), Cumhuriyet'in Mekanları Zamanları İnsanları, Ankara, ODTU Yayınları, 169-186.

Yörükan, T. (2012) Sosyolojik ve Sosyal Psikolojik Görüş Açısıyla Şehir Konut ve Mahremiyet, İstanbul, Atatürk Kültür Merkezi. http://www.emlakjet.com/haber/foto-galeri.php?imaj_ id=6550\#foto_td [Erişim Tarihi: Mart, 2015]. 